\title{
REFERÊNCIA DÊITICA IN ABSENTIA: UMA DISCUSSÃO PRELIMINAR
}

\author{
Caio César Costa Santos ${ }^{1}$
}

\begin{abstract}
RESUMO: Este texto aponta algumas discussões em torno da teoria do referente in absentia formulada por Bühler (1967). Nos estudos linguísticos, não há aparentemente uma reflexão mais precisa em torno desta abordagem. Partindo da interface entre a semiótica peirceana e a filosofia da linguagem em Frege (2009), o autor perpassa sob um itinerário discursivo que retoma a noção de referente cujo caráter representativo sugere uma dimensão secundária entre o objeto designado por um ponto de referência dêitica local e a referência construída com base no posicionamento psicológico do receptor do texto. A partir da poesia de Cecília Meirelles (1990), analisamos as retomadas textuais do uso anafórico dos demonstrativos, sugerindo que o ponto de vista dêitico circunscreve tanto numa dimensão semântica de seu uso, como numa dimensão discursiva.
\end{abstract}

PALAVRAS-CHAVE: Referência dêitica. Representação. Demonstrativo.

\section{INTRODUÇÃO}

Na obra intitulada Teoría del Lenguaje, Karl Bühler (1967, p. 195) cunha o termo Deixis am Phantasma para a referência a objetos ausentes do espaço perceptivo do falante. Através de um fundamento psicológico e fenomenológico da referência dêitica prévia, Bühler define o campo de relações espaço-temporais em Zeigfeld e Symbolfeld, porém, além destes dois campos de percepção, o linguista designa um terceiro campo denominado de a "situação am phantasma". A partir deste último "campo", Bühler torna possível, ao receptor do texto, a função de remeter às expressões anafóricas que fazem parte do mundo da ficção ou, nos termos buhlerianos, à fantasia construtiva. Isso quer dizer que as categorias linguísticas tais como Aqui-Agora-Eu, caracterizadas como ponto fixo e indicador de encruzilhadas, participam também de um processo anafórico in absentia. Este processo, ao mesmo tempo em que é demonstrativo, é retrospectivo, pois aponta para espaços não visíveis na própria superfície do texto.

Neste artigo, a nossa hipótese preliminar é a de que o espaço perceptivo do receptor do texto não constitui a superfície total da textualidade, pois, há, na estruturação deste espaço perceptivo, uma base psicológica de mostração anafórica in absentia. Segundo esta perspectiva, os sentidos do texto são co-construídos na própria superfície da presente instância de discurso, mas, no interior desta mesma

\footnotetext{
${ }^{1}$ Mestre em Letras pela Universidade Federal de Sergipe, UFS. Email: caio-costa@live.com
} 
instância, por intermédio de intuições, é possível construir uma linha referencial imaginária, ausente aos olhos do corpo, mas presente aos olhos do espírito.

O interlocutor é quem tem a função de um detetive porque escruta das próprias palavras pequenos sinais, às vezes, negligenciados durante o processo de interpretação. Seguido esta premissa, o emissor e o receptor do texto, no interior de uma relação intuitiva de objetos ausentes, possuem, ambos, disposições mentais as quais permitem ao emissor da situação linguística iluminar os objetos não visíveis e, ao receptor, cabe interpretar os objetos presentes nesta situação imaginada. Partindo deste diálogo, a nossa discussão gira em torno do seguinte problema: se o espaço perceptivo não constitui a superfície total do texto, como a deixis am phantasma é construída linguisticamente?

\section{IMPLICAÇÕES ACERCA DO TRATAMENTO DO CARÁTER REPRESENTATIVO DO REFERENTE IN ABSENTIA À LUZ DA SEMIÓTICA E DA FILOSOFIA DA LINGUAGEM}

Sabemos que a língua, como aparelho formal da linguagem, é arbitrária e a sua natureza é dupla, sendo assim, os valores distribuídos no sistema linguístico têm múltiplas funções, uma vez que um único signo pode conter múltiplos valores de existência e de significação na trama do discurso. De acordo com o que a semiótica peirceana comenta: o signo, na estrutura ausente da língua, somente tem existência em virtude da relação com o caráter representativo do objeto a que ele representa. Por este contexto, os signos, sejam eles, linguísticos ou pictóricos, são abstratos por natureza, contudo, tornam-se perceptíveis graças ao fenômeno de ilusão de imanência. Ou seja, o espectador aponta para "situações" do espaço real do texto como se estivesse vivendo-as no momento; é como se ele apontasse para determinado "lugar", neste espaço perceptivo, sem estar apontando para algo.

O signo, designatum, é capaz de designar alguma coisa, o objeto ou a situação, mas não em todos os seus aspectos e caracteres, pois, a materialidade do sistema linguístico é também uma entidade profunda abstrata e invisível aos olhos do

espectador. Partindo desta característica, o traço primário de todo o processo de comunicação entre dois indivíduos, bem lembrado por Jakobson (1975), está 
envolvido na simetria emissor-receptor, cuja unidade estabelecida é de natureza psicofísica, mas, a relação com os objetos invisíveis à interação verbal é de segunda ordem, pois o que o espectador "vê", no reflexo do cristal de tempo, é a representação do objeto na forma de um signo, ou seja, a forma secundária do objeto.

A semiótica peirceana nos diz que o índice é o representâmen cujo caráter representativo consiste na forma secundária do referente, ou seja, este mesmo referente contém o pensamento como parte, na formulação de Frege. Para a nossa discussão, presumimos que o espectador do texto é quem toma a situação linguística am phantasma por intermédio de uma imagem, real ou fictícia, construída com a força da mente. Então, ele, o observador e também analista, toma o objeto primariamente como indício, pois, o signo linguístico, enquanto índice, toma o "lugar" de referente. Nesta relação, o valor de existência do objeto, o qual o observador aporta, é uma imagem táctil consciente movente. Na visão de Brugmann apud Bühler (1967, p. 206), há, aí, uma estreita vinculação orgânica da imagem real perceptiva com a imagem intuitiva do objeto.

No texto Sobre o sentido e a referência (1892), o lógico e matemático Frege (2009) questiona se a relação entre o sentido e a referência constitui uma mera relação entre objetos ou uma relação entre (pro)nomes e sinais de objetos. Os nomes, arbitrariamente expressos, não pertencem a qualquer objeto, pois, a partir de uma regra convencional, os objetos que possuem uma relação existencial com os nomes não têm apenas uma referência, mas mais de um ponto de referência, pois, conforme postula Frege (2009), uma referência a um único objeto pode receber mais de um sinal. Este sinal designa o modo de apresentação do referente ao espectador em sua segunda forma.

Porém, depreender o sentido de uma sentença verbal não significa que a existência de uma referência é determinada, segundo à referência de um sinal, uma vez que o objeto, na lente do espectador, é um caractere sensorialmente perceptível, pois, "quando dois seres [o emissor e o receptor] imaginam o mesmo objeto, ainda assim, cada um tem a sua própria ideia" (FREGE, 2009, p. 135). A ideia ou a intuição que temos de um referente é a de ser uma imagem interna. Esta imagem interna, 
construída com a força da mente, está impregnada de emoções cuja intuição abstrata do objeto é, em parte, subjetiva. Vejamos a seguinte formulação:

Alguém observa a lua através de um telescópio. Comparo a própria lua à referência; ela é o objeto da observação, proporcionado pela imagem real projetada pela lente no interior do telescópio e pela imagem retiniana do observador. A primeira imagem comparo ao sentido, a segunda, à ideia ou à intuição (FREGE, 2009, p. 135).

Com a imagem intuitiva do referente torna-se possível construir um ponto de referência o qual mostra-se, inicialmente, "inexistente" na situação linguística corrente de uso do espaço perceptivo. De acordo com a formulação de Frege (2009), a imagem real projetada pela lente do telescópio e a imagem retiniana projetada pelo observador constituem, ambas, a referência e o sentido do objeto. Esta relação entre a imagem e a percepção admite que a imagem retiniana do observador $A$ [o emissor] pode tornar-se visível ao observador $B$ [o receptor] e que o observador A pode projetar a sua própria imagem, a partir das luzes reincidentes do reflexo do cristal do telescópio. Segundo Frege, deste modo, é possível demonstrar como uma imagem intuitiva pode, ela mesma, ser tomada pelo referente. Contudo, esta mesma imagem nunca será para o observador A [o emissor] o que ela é refletidamente para a imagem interna do observador $B$ [o receptor], porque cada observador carrega em si experiências próprias, internas ou externas, associadas às ideias, bem como às palavras.

Nesta relação, o observador $B$ [o receptor] pode ver uma diferença, mesmo marginal, que o observador $\mathrm{A}$ [o emissor] não conseguiu perceber no ato de observar abstrativamente o referente. No que diz respeito à imagem retiniana, cada um dos observadores tem sua própria intuição, já que o sentido da referência não é o próprio objeto tão ele e somente.

Pertencem ainda a essas possíveis diferenças, os coloridos e os sombreados que a arte poética e a eloquência procuram dar ao sentido. Tais coloridos e sombreados não são objetivos, mas devem ser evocados pelo próprio ouvinte ou leitor, conforme às sugestões do poeta ou do orador. Se não houvesse alguma afinidade entre as ideias humanas, a arte seria certamente impossível, embora não se possa averiguar exatamente até onde estas correspondem às intenções do poeta (FREGE, 2009, p. 136). 
Cada referente se comporta diferentemente como um signo na lente do observador, pois, o pensamento, por si só, não torna aquele referente existente ao espectador. Além da existência do referente real percepcionado, coexistem o valor de verdade, a referência e o pensamento, mas deve este pensamento ser considerado o sentido total de um discurso? Segundo Frege (2009), o pensamento não pode ser a referência total do referente percepcionado, pois atrelado ao pensamento, coexiste o sentido do contexto do referente, como o pensamento da sentença de que "a estrela da manhã é um corpo iluminado pelo sol" é diferente do da sentença "a estrela da tarde é um corpo iluminado pelo sol" (FREGE, 2009, p. 137).

A este caso, em particular, o pensamento, por si só, não depreende conhecimento linguístico, mas somente $\mathrm{o}$ ato de pensar associado à referência 0 qual, no sentido fregeano, toma o valor de verdade do referente percepcionado, como o de que a estrela é a mesma entre ambos turnos do tempo. Por valor de verdade de uma sentença, Frege entende a circunstância de ela ser verdadeira ou falsa, mas até que ponto o observador de um objeto pode discernir se o que ele vê é genuinamente verdadeiro?

A este ponto, na concepção fregeana, pode-se refletir que o sentido do todo de uma sentença verbal contém o pensamento como parte secundária e, no ato de expressar esta sentença, associamos-a a pensamentos secundários. É importante entender que o valor de verdade não é propriamente o sentido, pois, até o logicismo de Frege designa que todo objeto é expresso por uma espécie de semiose. Este objeto, posto como tal, é representado por via de um signo e designa não somente uma experiência, mas um conjunto de experiências individuais, como postula a tradição peirceana.

A Semiologia e a Semiótica têm uma dupla origem: os manuscritos de Saussure e os escritos de Peirce, respectivamente. A Semiótica inaugurada por Charles Morris (1976) e, posteriormente, por Charles Peirce (1977), constitui a função representativa de um referente e a Semiologia constitui o processo de significação ou de construção de sentidos de um referente. A Semiótica, parte integrante da Semiologia, é o instrumento de análise das ciências humanas, sociais e 
também exatas. Segundo a teoria semiótica, o signo representa determinado objeto espacial em relação à referência, o designatum, mas representa este objeto em todos os seus caracteres, referindo-se também à imagem intuitiva e não tão somente real.

Peirce (1977) afirma que os signos, eles mesmos, são divisíveis e seguem a tricotomia: a) o signo em si como existente real; b) a relação existencial do signo com o referente; c) e a relação do interpretante com o referente. Para a referência a objetos ausentes do espaço perceptivo, seguindo a tricotomia apresentada por Peirce, é possível pensar nas seguintes proposições formuladas também no seio do fundamento da teoria dos signos: a) nem todo o signo refere, de fato, a um objeto real existente; b) a relação existencial do signo para o objeto é primária e secundária; c) e a relação do interpretante com o objeto exige um modo de apresentação particular primariamente do signo e secundariamente do objeto.

Um signo, ou a representação a que se refere o objeto, está associado a caracteres gerais que o objeto passa a possuir, como por conta de sua conexão dinâmica (incluindo a espacial), como por conta do sentido ou da memória da pessoa para quem serve como um sinal (PEIRCE apud LAHUD, 1979, p. 81).

Um objeto individual não tem sentido sem a existência de uma unidade de signos no interior de uma conexão dinâmica e também espacial. Este fundamento semiótico evoca o caráter mnemônico do sentido representado na memória pelo espectador. Numa relação semântica, que é a semiose, o sistema de signos está ligado às leis psicológicas ou do pensamento. No caso do signo, sendo um índice, por exemplo, podemos considerá-lo como uma porção extraída do referente em sua forma primária, constituindo o índice e o referente, a sua forma secundária. Nesta perspectiva e, levando em consideração, o problema do referente in absentia, o receptor do texto toma o signo primeiramente em sua forma secundária e, através do índice, extrai do signo caracteres não visíveis ou ausentes.

Os índices, em forma de signos, são conhecidos, na língua, como os dêiticos. Os dêiticos mais conhecidos na literatura são o "eu", o "aqui" e o "agora". Para Benveniste (1966), o "eu-aqui-agora" significa o ponto axial do campo de interação verbal e, para Bühler (1967), significa o indicador de encruzilhadas, ou 
seja, o Zeigfeld ou o campo demonstrativo de relações espaço-temporais. Como Hanks (2008) afirma: há vários campos de interação que exige outros campos de monitoramento mútuo, desde o simbólico, o cultural, o interacional, o capital, etc.

Em contrapartida, nos estudos linguísticos, das letras e das artes, 0 Symbolfeld constitui o campo simbólico que envolve os movimentos pictóricos, ou seja, as formas geômetras dos afetos na visão tridimensional da imagem visual de uma obra prima projetada pela lente do espectador ao extrair, desta obra, índices formalizados com a força da mente. O texto verbal ou não verbal é relativo ao campo dêitico de relações entre dois indivíduos, relativo também à interação verbal, na área da Linguística, como subárea a Linguística de Texto. O objeto de descrição do ramo da Linguística é a língua, na forma autônoma e arbitrária, o objeto de descrição da Linguística de Texto tem caráter semelhante: a arbitrariedade dos sentidos do texto.

Cada traço primário compõe o sentido do texto, mas não o seu sentido total. Além da superfície textual, estão implicadas outras estruturas sociais, psíquicas, culturais, cognitivas. O texto representa o mundo por intermédio de signos, estes signos podem ser existentes na realidade e existentes na imaginação. Os estudos da área como em Koch (1979) e Marcuschi (2012) definem o texto como uma estrutura complexa que tem o sujeito como o agente, ele, o próprio sujeito, significa o "eu" da situação linguística. Uma das polêmicas dos estudos enunciativos (ou da enunciação) é a relevância da situação extralinguística: o contexto.

Por um longo tempo, Koch e Marcuschi definiram o texto como um processo de operação cognitiva mutuamente preservada na mente dos interlocutores. Estes dois teóricos do texto fundamentaram os seus estudos em um dos grandes pesquisadores da gramática de texto da década de 1970, Van Dijk. Para Van Dijk (2012), a partir de uma abordagem sociocognitiva, o texto é caracterizado como uma estrutura complexa porque envolve processamento, interpretação, engajamento por parte dos interlocutores, como também envolve percepção, atenção, memória e reativação na construção e reconstrução de referentes.

À luz da semiótica peirceana, o termo em latim designatum de cuja demonstração é o demonstratum expressa o sentido da referência do objeto demonstrado ou imaginado. O sentido da referência do objeto imaginado configura- 
se como o modo de apresentação deste objeto representado por via de um signo indexical. Na língua, os pronomes demonstrativos são como os nomes próprios, pois representam nomes e, por isso, têm um código e uma função particular.

Segundo Jakobson (1984, p. 42), no texto Shifters, verbal categories and the russian verb, "os nomes próprios, tratados no controverso ensaio de Gardiner como um problema muito nodoso de teoria linguística, tomam um lugar particular no nosso código linguístico: o significado geral de um nome próprio não pode ser definido sem uma referência ao código". No circuito linguístico da comunicação, o emissor representa o falante e o receptor outro falante, ambos estão conectados por via do código linguístico e por via do canal por onde veicula a mensagem verbal. Externa a esta situação verbal, o termo em latim demonstratum desempenha um papel particular que, como shifter, "é distinguido de todos os outros constituintes do código linguístico pela sua referência à mensagem estabelecida fora do contexto espacial" (JAKOBSON, 1984, p. 43).

Se o referente demonstrativo (e indexical) depende do contexto de uso da ocorrência, aquilo que complementa o contexto espacial é o modo de apresentação do objeto não visível ao espectador, o que faz crer que a referência ao objeto no espaço perceptivo do falante é também arbitrária. Émile Benveniste (1989) caracteriza a subespécie dos dêiticos, os demonstrativos, como elementos ostensivos. Segundo os seus escritos, as partículas demonstrativas têm um grau de ostensão particular. Esta característica de ostensão pertence elementarmente à natureza das categorias linguísticas dos pronomes demonstrativos. Os índices de ostensão, particulares dos demonstrativos, dispõem-se em planos temporais da enunciação que têm efeito intermediário, expressivo e pulsante.

Além de ponto axial, cada Je expresso na situação linguística aponta para uma dimensão discursiva particular de orientação, seja o presente linguístico, seja o passado simples (aoristo). O fenômeno de translocação das categorias linguísticas dêiticas expandem as coordenadas do espaço perceptivo do falante e tem relação com a dimensão discursiva representada linguisticamente pelos pronomes demonstrativos. 
Se uma partícula linguística demonstrativa abre outras camadas de discurso no interior da superfície total do texto, tratar de uma situação linguística exterior à unidade semântica do texto diz respeito ao tratamento das expressões linguísticas de demonstração. A situação linguística in absentia tem relação existencial com os particulares dêiticos de demonstração, pois, eles são indicadores naturais de orientação espacial no sistema da língua.

A análise dos signos mostrativos, por exemplo, nos descobrirá que homens como Wegener y Brugmann estavam no caminho correto quando descobriram a função dos demonstrativos e, de fato, utilizaram se não a palavra, e sim o conceito geral $<<$ sinais $<<$. Pois ocorre que os demonstrativos no caso limite (os demonstrativos puros), segundo aparecem como partículas indeclináveis não somente no indoeuropeu primitivo, mas também no dia de hoje em nossa língua, e de modo mais claro em seu emprego prático (BÜHLER, 1967, p. 73).

As expressões linguísticas são objetos parciais da linguística que, comparados com a representação linguística, mostram, demonstram estruturas próprias. No domínio das línguas indoeuropeias, os demonstrativos puros definem o campo de significação do visível que, posto diante dos olhos, adentra ao espaço perceptivo do falante. Com outras palavras, o sinal envolvido nas raízes das línguas indoeuropeias designa o modo de mostrar e de descobrir os objetos em torno do espaço e de conduzir o espectador diante às formas espessas destes objetos.

Se a palavra grega deixis e sua tradução latina por demostratio significam também a demonstração lógica, e assim a põem no mesmo nível que a demostratio ad oculos sinalizada pela raiz, também compreenderemos isto muito bem pelo sentimento próprio da linguagem: o que é conduzido deve chegar, seja de um modo ou de outro, precisamente à $<<$ visão $<<$ sensível ou lógica (BÜHLER, 1967, p. 81).

O ato de mostrar é próprio e intuitivo da espécie humana e animal. Os sons, como por exemplo, os sinais de ruídos entre dois grupos estranhos de animais, ampliam, fonematicamente, o próprio horizonte de percepção diante os olhos do animal. Segundo Bühler (1967), neste caso, o índice é, além de grito de susto, a impressão de perigo entre os rebanhos. No espaço perceptivo, a função do sinal é vitalmente importante tanto para a sobrevivência no mundo animal, quanto para a comunicação entre espécies. Mas, os animais não produzem palavras semelhantes 
às dos humanos, não produzem nada análogo aos gestos dos braços e dos dedos como os demonstrativos puros o fazem. Se um signo concreto, como existente real, funciona como fundamento de representatividade, em virtude de quais caracteres linguísticos aqueles animais percepcionaram a representação de perigo?

Para Bühler (1967, p. 85), "no caso de ser signo nunca são mais que momentos abstratos, em virtude dos quais e com os quais o concreto atua como signo". No teatro, por exemplo, o espectador toma a máscara e os gestos, as palavras e as ações das personagens como sinais. Diante dos olhos do corpo, o espectador vê as propriedades materiais por si, diante dos olhos do espírito, o espectador "vê" as propriedades espirituais do objeto representado como signo. Os objetos ali percepcionados pelo espectador não comportam as propriedades concretas em sua plenitude, ao contrário, "pode ocorrer que somente este ou aquele momento abstrato resulte relevante para sua missão de funcionar como signo" (BÜHLER, 1967, p.92).

Os modos de sinalizar são diversos. Tudo o que é linguisticamente dêitico coincide com o campo mostrativo da linguagem, a saber, o demostratio ad oculos y ad aures. Associado a este, há um terceiro campo que Bühler caracterizou de deixis am phantasma, no qual os signos linguísticos podem receber valores de campo distintos da situação verbal por intermédio de uma imagem intuitiva da situação linguística presente. O termo "imagem intuitiva" deve ser aqui compreendido em seu sentido metafórico. Ocorre que, na situação linguística concreta, há uma multiplicidade de signos indiretos que pertencem à classe dos demonstrativos (gestos, sons, palavras, imagens). Quando o objeto e aquele que o designa estão na mesma linha referencial que o falante, é interessante observar que este objeto não afeta totalmente o campo de direção real.

Quando um enfermo quer sinalizar ao médico no próprio corpo um lugar que dói, tocará dizendo "aqui" e, em certas circunstâncias, continuará dizendo "ali" para indicar um lugar do corpo que o é inacessível naquele momento (BÜHLER, 1967, p. 166).

Neste exemplo, o uso anafórico de "ali" corresponde ao latim ille e alude a algo que não está imediatamente presente, porém, segundo Bühler (1967, p. 168) 
"como um complexo psicanalítico, refere a minha consciência táctil e perceptiva que tenho do objeto naquele momento". No âmbito da memória imediata, os signos linguísticos dêiticos não podem ligar-se integralmente ao espaço perceptivo do falante.

\section{O USO ANAFÓRICO DOS DEMONSTRATIVOS NA CONSTRUÇÃO DE SENTIDOS DO TEXTO}

Diante das discussões estabelecidas no tópico anterior, podemos presumir que o movimento fórico que é encontrado em nossa língua tem a ver com as remissões textuais dos pronomes demonstrativos. Como nenhum outro elemento linguístico, a classe linguística dos demonstrativos proporciona uma expansão das coordenadas dêiticas espaciais. Ou seja, o "lugar" o qual os indicadores de terceira pessoa apontam não está na presente instância do discurso, embora o modo de apresentação do elemento engatilhador demonstrativo aconteça primeiramente no espaço perceptivo do falante.

$\mathrm{Na}$ teoria do texto, dos sete critérios de composicionalidade da textualidade, está um que é indiscutivelmente essencial: o critério da situacionalidade. Nele, é levado em consideração a emergência do contexto. Hanks (2008) foi um dos teóricos da terceira geração que esteve preocupado com a condição situacional do princípio da textualidade. Este estudioso não somente disserta acerca do campo dêitico de relações espaço-temporais, mas inclui aí uma descrição que nos é importante para o contexto do referente in absentia: o critério da emergência. Por um longo tempo, muitos teóricos estiveram preocupados com a noção de contexto, entre eles, encontra-se Levinson (2007). Porém, a unidade do contexto, como ordem semântica, não formula perspectivas em torno do ponto de deslocamento da referência dêitica. O que há de novo na teoria de Hanks é que ele inclui o vocábulo emergence (emergência).

Isso quer dizer que o modo de apresentação do anafórico demonstrativo tem muito a ver com o ponto focal de referência dêitica, pois um único demonstrativo não aponta para um único lugar; o demonstrativo emerge da situação discursiva do 
contexto situacional e alcança um modo de apresentação no discurso único. O uso de "aquele" ou "aquilo", muitas vezes, tem a ver com o nível de interpretação do texto. Sabemos que o texto é uma unidade semântica complexa de cadeias ramificadas que estilizam o modo de apresentação do discurso. Cada receptor do texto, assim como o emissor, carregam em si subjetividades, experiências individuais e modelos de mundo distintos. Sendo assim, cada sentido atribuído reflete no modo de vivência de cada ser.

llustraremos, a seguir, alguns exemplos de uso anafórico dos demonstrativos a partir da poesia de Cecília Meireles (1990) no livro Ou isto ou aquilo. Nele, é possível observar como um único elemento dêitico demonstrativo transforma todo o processo de construção de sentidos para o texto. A poesia de Cecília é mesclada com tons vivos e musicais, o leitor adentra numa atmosfera mágica de percepção das coisas do mundo. O movimento rítmico faz surgir uma poesia simplificada com a força notória do tempo. Os versos são arquetipicamente construídos para dar uma noção de clareza e movimento. O que torna Cecília uma poeta diferente das demais é o talento especial para lidar com as palavras. Vejamos:

Exemplo 01:

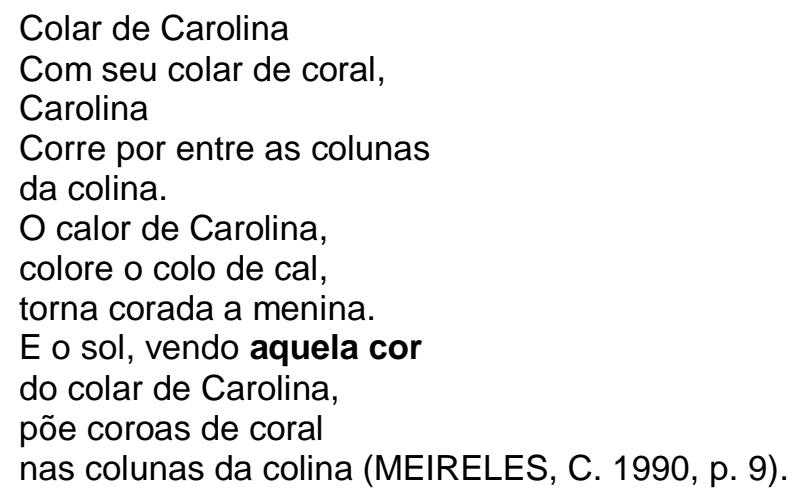

Neste poema, o ethos de Cecília está aflorado. O contorno da escritura das palavras reflete a emoção do eu-lírico de desenfrear uma multiplicidade de ações imperativas ("corre por entre as colunas"/ "colore o colo de cal"/ "põe coroas de coral"). Isto é medido com a delicadeza expressiva dos versos sonorizados e, mais, com o ato de brincar com as palavras ("colar"/"coral"/"carolina"). O leitor tem a 
sensação de participar deste acontecimento que é o florescer e o germinar da natureza. O sol quando se põe reflete o colar colarizado de Carolina, iluminando as coroas de coral nas colunas da colina. A impressão das cores também é fantasticamente conduzida pela emoção, estas cores não estão descritas, mas formam artisticamente a composição do fenômeno da natureza: o amarelo do Sol, o verde das colinas, o branco do colar, etc.

Quanto ao uso de anafóricos demonstrativos, temos a percepção do elemento linguístico "aquela cor". A partir das formas do verbo no imperativo como em "corre", "colore", a expressão rítmica "dar cor" aos versos de Cecília, "colore o colo de cal, tornando corada aquela menina". Neste caso, o uso do elemento anafórico demonstrativo "aquela cor" reflete na construção de sentidos de todo o texto. É como se o engajamento das ações de Carolina fossem reais a partir do elemento dêitico localizador "aquela cor". O uso deste anafórico, que é também encapsulador, encoleriza Carolina, assim como o leitor. Então, vê-se que, de acordo com a teoria do referente in absentia, o espaço perceptivo real do falante toma uma nova dimensão discursiva por meio do uso do pronome demonstrativo de terceira pessoa "aquela". Este demonstrativo encapsula toda uma porção prévia, desde o colar de coral às colunas da colina.

Exemplo 02:

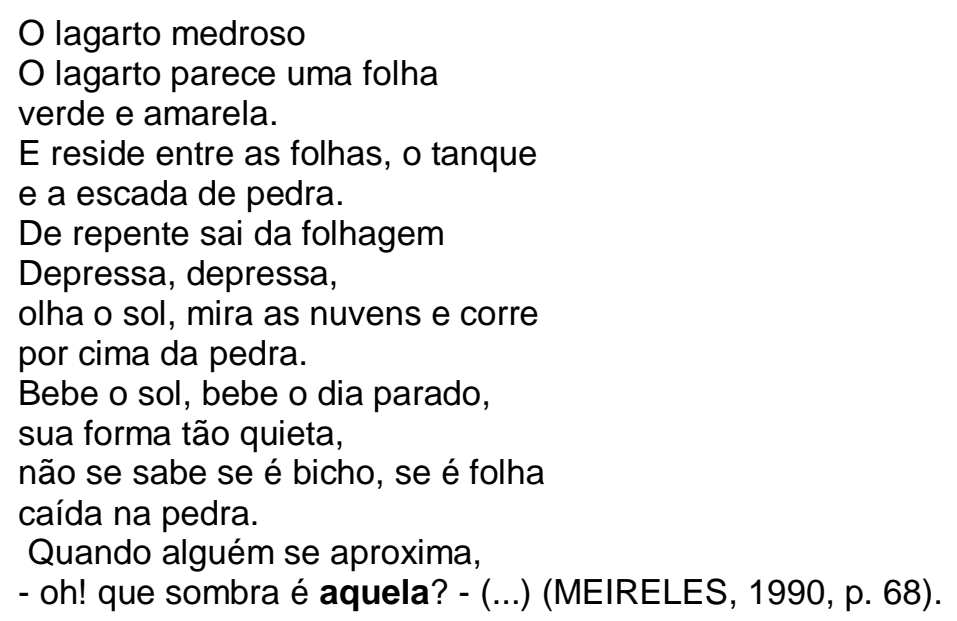

Neste poema, o eu-lírico está revestido de deslumbramentos. O personagem, o lagarto, vive uma história melancólica que vislumbra acontecimentos 
próprios da espécie. como a camuflagem ("o lagarto parece uma folha verde e amarela"/"não se sabe se é bicho, se é folha"). Ele, o lagarto, parece adentrar em um lugar repleto de meandros e esconderijos ("reside entre as folhas, o tanque e a escada de pedra"). Este lagarto também toma sol e observa paulatinamente o passar do tempo ("bebe o sol"/ "bebe o dia parado"). Todo o poema forma uma conduta que é própria da trajetória de vida de um réptil, como o lagarto.

O uso do elemento anafórico demonstrativo é apresentado ao leitor como uma forma de surpresa, espanto ou assombro justamente "quando alguém se aproxima". O demonstrativo "aquela" categoriza, mas não define quem, de fato, é aquela sombra. É lícito observar que o poema transfigura-se esteticamente para uma dimensão que circunscreve o estado de ânimo entre o lagarto, o personagem principal, e alguém que se aproxima, inesperadamente. $O$ espaço perceptivo do poema é caracteristicamente definido como geográfico e natural, uma vez que engloba o ecossistema dos répteis. Mas, podemos perceber que, a interpolação do demonstrativo na última estrofe transloca o poema para uma condição situacional espontânea e atemporal.

\title{
Exemplo 03:
}

\author{
Ou isto ou aquilo \\ Ou se tem chuva e não se tem sol, \\ ou se tem sol e não se tem chuva! \\ Ou se calça a luva e não se põe o anel, \\ ou se põe o anel e não se calça a luva! \\ Quem sobe nos ares não fica no chão, \\ quem fica no chão não sobe nos ares. \\ E uma grande pena que não se possa \\ estar ao mesmo tempo no dois lugares! \\ Ou guardo o dinheiro e não compro o doce, \\ ou compro o doce e gasto o dinheiro. \\ Ou isto ou aquilo: ou isto ou aquilo... \\ e vivo escolhendo o dia inteiro! \\ Não sei se brinco, não sei se estudo, \\ se saio correndo ou fico tranquilo. \\ Mas não consegui entender ainda \\ qual é melhor: se é isto ou aquilo (MEIRELES, 1990, p. 72).
}

Neste poema, concentramo-nos a atenção na composição das estrofes na qual os sentidos são construídos com base em um jogo de valores opositivos como: "se eu faço isto, eu não faço isto". Este jogo de valores é distribuído durante todo o 
poema, iniciando a conjunção designativa de oposição, o "ou" ("ou se tem chuva e não se tem sol"/"ou se tem sol e não se tem chuva!"). Mas, na quarta estrofe, a ritmização do jogo de valores opositivos perde a força em "é uma grande pena que não se possa estar ao mesmo tempo nos dois lugares". Neste caso, a poeta sinaliza a justificativa do renomado cientista Isaac Newton, a de que dois corpos não podem ocupar o mesmo espaço (a teoria do relativismo). Por conseguinte, na sexta estrofe, a poeta fica a mercê da dúvida "ou isto ou aquilo: ou isto ou aquilo". O "isto" forma uma ideia de proximidade e o "aquilo" forma uma ideia de distanciamento, comprovando a teoria de Newton; a de que dois corpos não podem ocupar de forma alguma o mesmo espaço.

\title{
CONCLUSÃO
}

Tecidas algumas discussões em torno do caráter representativo do referente in absentia, concluímos que a formação do campo dêitico de relações espaçotemporais é intermediária, uma vez que envolve tanto a relação primária do referente demonstrativo no espaço perceptivo do falante, como a relação secundária deste mesmo referente. A língua, por si só, é autônoma, mas, construída em torno do pensamento e, com base nas orientações pedagógicas da semiótica peirceana, adere a uma perspectiva de translocação do ponto focal da referência dêitica. Visto do ponto de vista focal da referência, o demonstrativo aponta para uma dimensão semântica de seu uso, visto do ponto de vista expandido, este mesmo demonstrativo aponta para uma dimensão discursiva, formando uma linha referencial imaginária.

\section{DEICTIC REFERENCE IN ABSENTIA: A PRELIMINARY DISCUSSION}

\begin{abstract}
This text points some discussions around the theory of the referent in absentia formulated by Bühler (1967). In linguistic studies, there no is apparently more precise reflection around this approach. Starting from the interface between peircean semiotics and the philosophy of language in Frege (2009), the author goes through a discursive itinerary that takes up the notion of a referent whose representative character suggests a secondary dimension between the object designated by a local deictic reference point and the reference built on the psychological position of the recipient of the text. From the poetry of Cecília Meirelles (1990), we analyze the textual resumptions of the anaphoric use of the demonstratives, suggesting that the deictic point of view circumscribes both a semantic dimension of its use, as in discursive dimension.
\end{abstract}

KEYWORDS: Deictic reference. Representation. Demonstrative. 


\section{REFERÊNCIAS}

BENVENISTE, É. Problemas de linguística geral II. São Paulo: Pontes, 1989.

BÜHLER, K. Teoria del lenguaje. Tradução de Julián Marías. Madrid: Revista de Occidente, 1967. Tradução do alemão: Sprachtheorie. Jena. Gustav Fischer, 1934.

FREGE, O. Sobre o sentido e a referência (1892). In: FREGE, O. Lógica e Filosofia da Linguagem. São Paulo: Editora da USP, 2009, p. 129-158.

HANKS, W. F. Língua como prática social: das relações entre língua, cultura e sociedade a partir de Bourdieu e Bakhtin. et al. Tradução de Anna Christina Bentes, Marco Antônio Rosa Machado, Marcos Rogério Cintra e Renato C. Rezende. São Paulo: Cortez, 2008.

JAKOBSON, R. Shifters, verbal categories and the russian verb. In: JAKOBSON, R. Russian and Slavic grammar. New York: Mouton Publishers, 1984, p. 41-58.

KOCH, I. A inter-ação pela linguagem. São Paulo: Contexto, 1995.

LAHUD, M. A propósito da noção de dêixis. São Paulo: Ática, 1979.

MARCUSCHI, L. Linguística de texto: o que é e como se faz? São Paulo: Parábola, 2012.

MEIRELES, C. Isto ou aquilo. Rio de Janeiro: Nova Fronteira, 1990.

MORRIS, C. Fundamentos da teoria dos signos. São Paulo: Editora da USP, 1976.

PEIRCE, C. Divisão dos signos. In: PEIRCE, C. Semiótica. São Paulo: Perspectiva, 1977, p. 45-76.

SANTOS, C.; LIMA, G. Relações dêiticas no plano da memória: algumas incursões dos sintagmas nominais demonstrativos. Signótica, v. 27, n.1, 2015, p. 351-373.

VAN DIJK, T. A. Discurso e contexto: uma abordagem sociocognitiva. Tradução de Rodolfo llari. São Paulo: Contexto, 2012.

Data da Submissão: 16/04/2018

Data da Aprovação: 26/07/2018 